\title{
ON THE RELATIVELY COMPOSITIONAL HOMOGENEITY OF ALBANIAN EASTERN OPHIOLITIC BELT
}

\author{
Çina A. \\ Institute of Geosciences, Energy, Water and Environment, Polytechnic University of Tirana, Str. \\ Don Bosko, Nr 60, Tirana, Albania, aleksandercina@gmail.com.
}

\begin{abstract}
Ophiolitic formation of Albanides, named as Mirdita zone, represents a compact segment of oceanic lithosphere of Middle-Upper Jurassic. Based on petrographic, geochemical and metalogenical features two types of belts are distinguished: western MORB and eastern SSZ types. In fact, structural and geological units as well as many other elements have shed light on lack of a sharp separation between the two belts. Recent investigations have evidenced that different ultramafic massifs of western ophiolitic formation, represent an evident variation of their composition from harzburgite to lherzolitic-types. This composition reflects a different grade of partial melting of upper mantle. Peridotites show a high variability, from $0.3-3.8$ wt.\% $\mathrm{Al}_{2} \mathrm{O}_{3}$, varying from small to highly extreme depleted peridotite.

On the contrary, Albanian eastern belt, it seems to be formed by a more homogeneous hartzburgitic mantle.

Detailed petrologic and metallogenic investigations have evidenced that this belt changes also from one massif to another, naturally at a smaller level, therefore it is easier to be named relatively homogeneous. It is distinguished by a higher melting degree, chiefly of hartzburgitic-type, characterized by whole and thick ultramafic section, as well as by metalogenic variety, mostly of metallurgic-type of chromite mineralization. It is supposed that rock-forming and mineraluzation processes have been developed not uniformly along the ophiolitic belt.

Keywords: Chromite, ophiolite section, SSZ-type.
\end{abstract}

\section{Introduction}

Albanides, the geological structure of Albania situated in south of Shkodra-Peja transversal fault, as a segment of Dinarides-Hellenides arc, are characterized by the presence of the ophiolitic formation.

The most important of geological event of Albania during Jurassic has been ocean spreading in Mirdita zone. Western belt is thought to have been composed by an ocean ridge, the eastern one by development of an immature island arc (Beccaluva et al., 1994; Shallo et al., 1995; Kodra et al., 1995). During Middle Jurassic, intraoceanic subduction was associated with formation of metamorphic sole. In the Early Tithonian, due to the compression regime, overlapping (obduction) of ophiolite occur.

The Albanian ophiolite formation has classically divided into western and eastern belts. The western ophiolitic belt, similar to western Mediterranean type as MORB-type ophiolite, is characterized by presence of lherzolite \pm hartzburgite type, plagioclase - rich basal cumulates, $\mathrm{TiO}_{2}$ - rich basaltic lavas $\left(1.5-2 \% \mathrm{TiO}_{2}\right)$, and by scarce chromite mineralization, chiefly of $\mathrm{Al}$ - rich refractory type. A particular Fe - Ti mineralization, related to Fe-gabbro, is also present. For this belt is characteristic 
the crystallization order: olivine+chromite+plagioclase+clinopyroxene and geochemical features of association high-Ti basalts, that an oceanic spreading system without any influence of subdacted related processes (Beccaluva et al., 1994; Shallo et al., 1995; Hoeck et al., 2002). The western ophiolite belt is originated from magmatic source that was less depleted, 5-10\% (Koller et al., 2009; Çina, 2010).

The eastern belt is si milar to eastern Mediterranean-type, as IAT-boninitic, SSZ setting of ophiolitetype, is characterized by presence of hartzburgitic-type mantle, pyroxene-rich basal cumulates and by $\mathrm{TiO}_{2}$ poor lavas of boninitic affinity with range down of $0.3 \%$.

This ophiolitic belt is particularly distinguished by high potential chromite-bearing mineralization of Cr-rich metallurgic type. Other types of mineralizations are occur also such as PGM and Nisulfide, associated with PGE. As is suggested by Nicolas et al. (1999), the slow spreading, oxygen fugacity and the cool action of overlayered crust have played their role in high chromite concentration.

The eastern belt is most depleted, about $25 \%$. This belt, the petrologic characteristics of the cumulate sequence, and the strongly underlying depleted mantle tectonics, along with geochemical features of lavas, indicate a suprasubduction generation of parental magmas (Beccaluva et al., 1994; Shallo et al., 1995). Their crystallization order is olivine + chromite, followed by clinopyroxene and/or orthopyroxene and then plagioclase. Generation of such magmatic system implies intra-oceanic subduction of a pristine lithosphere.

\section{Geological setting}

The Albanian ophiolitic formation is situated in eastern part of Albania, about $250 \mathrm{~km}$ long. Its northern part is bounded by Shkoder - Peja transform fault. The Labinot - Diber transversal fault zone separates the northern and southern ophiolitic formation.

The Albanian ophiolite formation is situated in the western flank of Korabi - Pelagonian microplate. The contact zone of this formation is usually marked by a narrow belt of metamorphic rocks of amphibolites, green schist facies and pre-ophiolitic volcano-sedimentary series.

The primary sedimentary cover of Albanian ophiolite consists of Late Jurassic radiolarian charts and flyschoidal sediments of Tithonian to Early Cretaceous age (Shallo et.al., 1995; Kodra et al., 1995). According to recent micro-paleontological investigations (Chiari et al., 2004) radiolarian chart formation located on top and within volcanics, in upper part is older than Upper Bajocian and younger than Lower Oxfordian, therefore it is thought to be of Middle Jurassic. The age of Albanian ophiolite calculated by $\mathrm{K}$ - Ar method, is $160 \pm 7.5 \mathrm{ml}$ years, and by $\mathrm{Rb}-\mathrm{Sr}$ method is $158 \pm 4.1 \mathrm{ml}$ years (Tashko et al., 1990, CRPG, Nancy, France).

\section{Petrological and metalogenic features}

Eastern ophiolitic belt consists of some ultramafic massifs, from Tropoja - Has of northeastern area, to the south and southeast, where are situated Kukes, Lura, Bulqiza, Shebenik-Pogradec massifs and some other occurrances in Bitincka, Devolli area (Figure 1).

Based on geophysical measurements, ophiolitic formation of eastern belt is very thick, 5 - 7 to 10 $12 \mathrm{~km}$ toward northeast. 


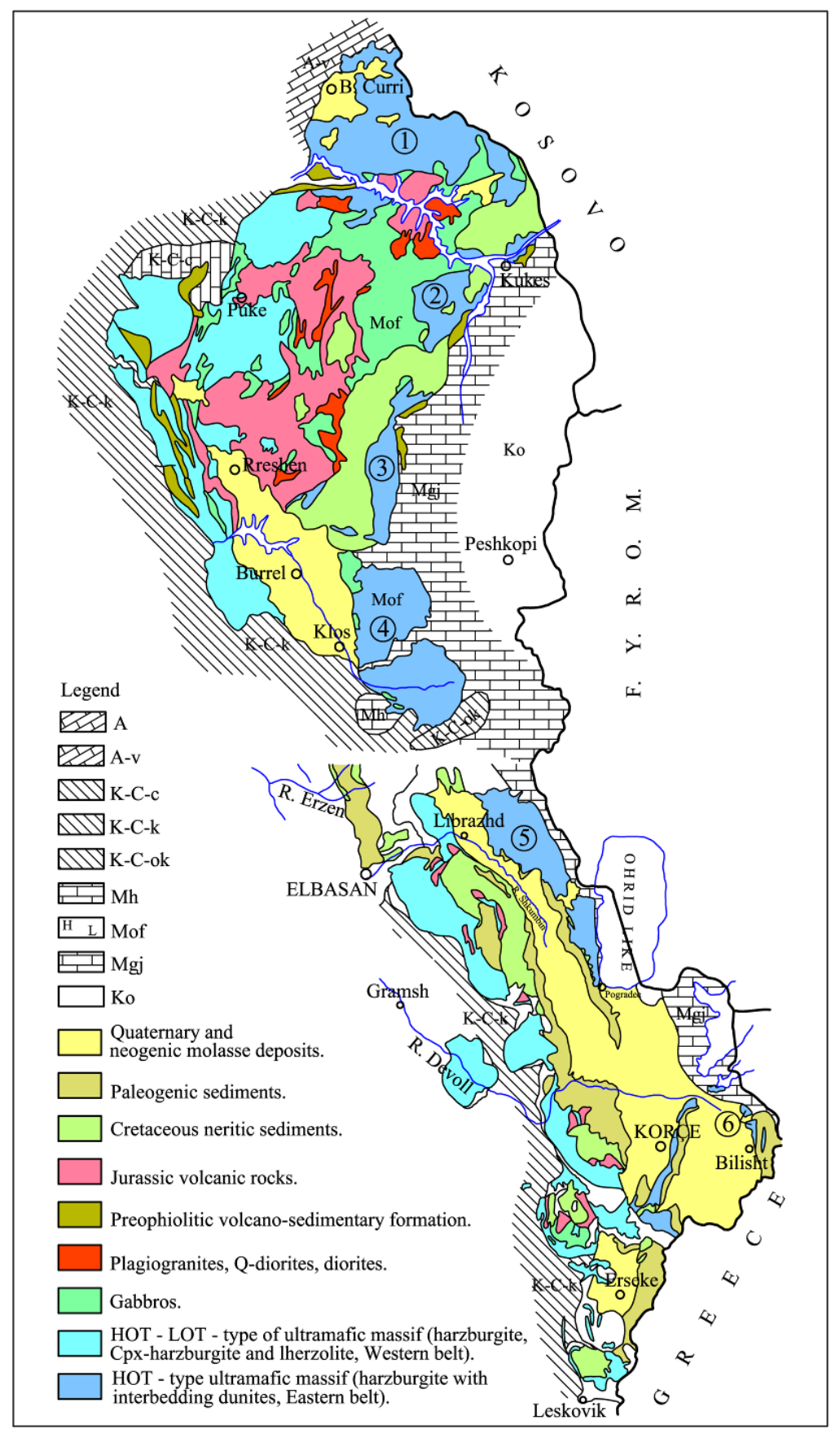

Figure 1 - Albanian ophiolitic formation. A-Albanian Alps; K-C- Krasta-Cukali zone; MMirdita zone: M-of- Mirdita ophiolites; Ko-Korabi zone. Ultramafic massifs, eastern ophiolitic belt: 1-Tropoja-Has, 2-Kukesi, 3-Lura, 4-Bulqiza, 5-Shebenik-Pogradeci, 6Bitincka.

Dominated rocks of this area are mantle ultramafics, chiefly mantle harzbugites, less dunites and transition zone dunites. Ultramafic cumulates, dunites, pyroxenites and wehrlites are thin, about 50 $-200 \mathrm{~m}$. Other part of crust sequence, the mafic, is very thick, about $1500-1800 \mathrm{~m}$. It should be noticed that in northeastern zone, occurs a large gabbro massif, named Kaptena, which covers a 
territory of $350 \mathrm{~km}^{2}$. This sequence is composed by different gabbro rocks, even amphibole gabbro and quartz gabbro. Small quartz diorite and plagiogranite massifs have intruded in gabbro sequence and in lower part of volcanic unit (Figure 2).

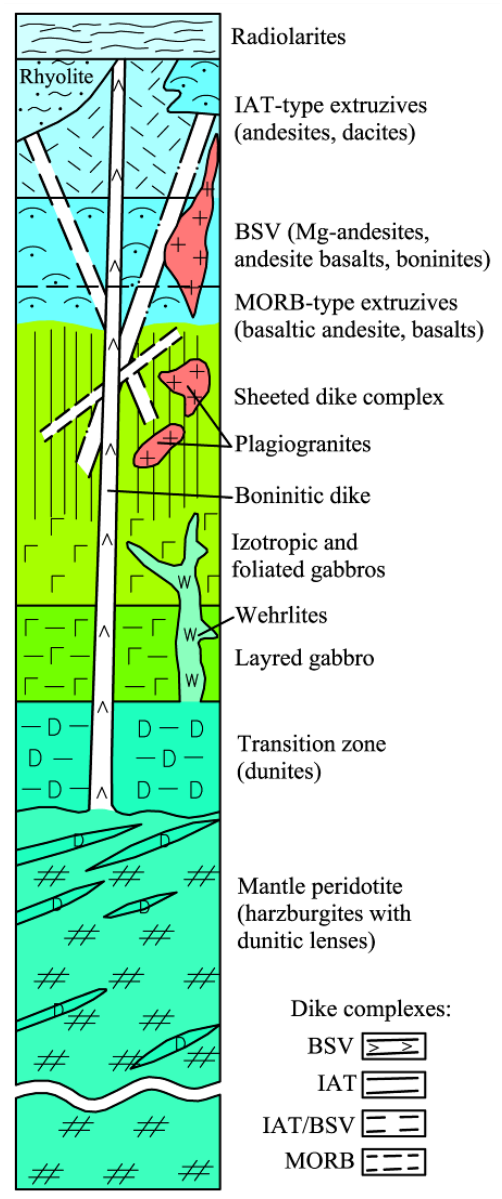

Figure 2 - Generalized column of eastern Albanian ophilitic belt.

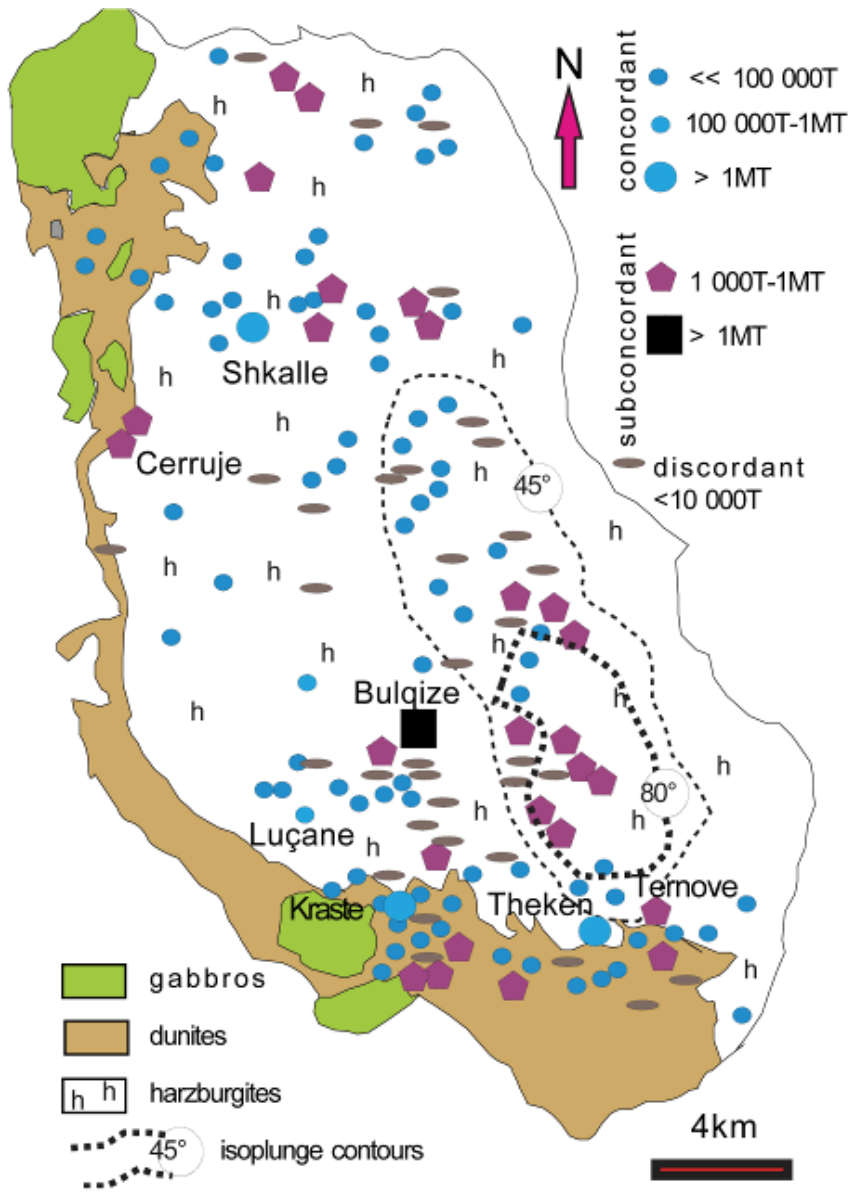

Figure 3 - Distribution of chromite ore bodies and their structural types of Bulqiza massif.

Extrusive volcanic rocks of IAT- type, with a considerable thickness of $1500-2200 \mathrm{~m}$, are represented by basalts, basalt andesites, boninites, dacites and rhyolites.

Presence of sheeted dyke complex is another distinctive feature of eastern belt. It is situated in northeastern axial part wth $1000-1200 \mathrm{~m}$ thickness. They perform an IAT boninitic affinity, but are also of MORB type (Manika, 1994; Shallo et al., 1995). Presence of boninites in eastern belt represents a significant petrologic interest.

Some ultramafic massifs show a relative variation regarding to rock-types, thickness of their sequences, metallogenic features, mineralization types, their potential and shapes of ore bodies. General characteristics of eastern belt are hartzburgite composition of mantle, highly magnesium composition of rock-forming minerals, of enstatite $\mathrm{En}_{90-92}$, as well as forsterite $\mathrm{Fo}_{90}-93$, a few $\mathrm{Al}_{2} \mathrm{O}_{3}$ and $\mathrm{CaO}$ (tenths of \%) and very stable composition of chromite ores.

\subsection{Tropoja-Hasi massif}

Tropoja - Hasi ultramafic massif has a special position, since it appears as a common node for two belts. This massif is large and is composed by mantle hartzburgites, as well as by transition zone 
dunites. In the central part of the massif occur pyroxenites and gabbro dykes. Main mineral is chromite, related to mantle hartzburgites and dunites of super-MOHO zone. Many occurrences with some average size and some deposits from 0.5 to 1 milion ton reserves occur. Ore bodies have lenticular - platy shapes and composed by ores with varied textures, whereas chromite itself belongs to $\mathrm{Cr}$-rich type with high grade metallurgic ores. Average chemical indicators are as following (Table 1): $\mathrm{Cr} /(\mathrm{Cr}+\mathrm{Al})=0.79-0.82$, while $\mathrm{Mg} /\left(\mathrm{Mg}+\mathrm{Fe}^{2+}\right)=0.60-0.65$. Some occurrences of chromite, related to relatively deeper mantle hartzburgites, belong to Al-rich-type with $(\mathrm{Cr} / \mathrm{Cr}+\mathrm{Al})$ about 0.65 . A special chromite type is that of schlieren chromite, associated by pyroxenite veins, distinguished for euhedral crystals of chromite, at size of some mm, and with highly Fe content $\mathrm{Mg}$ / $\left(\mathrm{Mg}+\mathrm{Fe}^{2+}\right)=0.40-0.45$ and $\mathrm{FeO}^{\text {tot }}=27.4-31.5 \mathrm{wt}$. $\%$. Another metalogenic distinction of Tropoja - Hasi massif is presence of unique mineralization in Albanian ophiolites, such as PGE, which occurs within schlieren chromite related to pyroxenite veins and magmatic brecciated dunites (Bregu i Bibes, Zherge, Shpati i Dajcit deposits).

Albanian eastern ophiolite belt; 1, 4, 6, 7, 9 and 10- chromite related to mantle hartzburgites and transition zone dunites from ultramafic massifs; 2- Fe-rich chromite PGE-bearing ores; 3- Al-rich chromite related to deeper Cpx-hartzburgites; 5 and 8- Al-rich chromite related to cumulate ultramafics; 11- Al-rich chromite related to lherzolite western belt massifs (Çina et al., 1986; Çina 2010); Vourinos (Greece) massif: 12-Xerolivado (Economou et al., 1986).

Table 1 - Representative electron microprobe analyses of chromite.

\begin{tabular}{|l|c|c|c|c|c|c|c|c|c|c|c|c|}
\hline & $\mathbf{1}$ & $\mathbf{2}$ & $\mathbf{3}$ & $\mathbf{4}$ & $\mathbf{5}$ & $\mathbf{6}$ & $\mathbf{7}$ & $\mathbf{8}$ & $\mathbf{9}$ & $\mathbf{1 0}$ & $\mathbf{1 1}$ & $\mathbf{1 2}$ \\
\hline $\mathrm{SiO}_{2}$ & 0.05 & 0.06 & 0.09 & 0.08 & 0.06 & 0.07 & 0.05 & 0.06 & 0.05 & 0.06 & 0.05 & 0.25 \\
\hline $\mathrm{Al}_{2} \mathrm{O}_{3}$ & 10.12 & 9.38 & 21.49 & 9.91 & 13.68 & 10.26 & 10.06 & 22.97 & 10.72 & 9.92 & 23.43 & 9.85 \\
\hline $\mathrm{Cr}_{2} \mathrm{O}_{3}$ & 59.06 & 50.74 & 46.7 & 59.22 & 52.52 & 60.45 & 60.45 & 42.92 & 58.76 & 60.66 & 44.53 & 59.58 \\
\hline $\mathrm{Fe}_{2} \mathrm{O}_{3}$ & 3.96 & & 5.2 & 4.3 & 4.18 & 2.03 & 1.85 & 4.18 & 5.62 & 2.57 & 2.88 & 4.78 \\
\hline $\mathrm{TiO}_{2}$ & 0.05 & 0.15 & & & & & 0.2 & 0.26 & 0.06 & 0.15 & 0.19 & 0.18 \\
\hline $\mathrm{MgO}$ & 15.32 & 7.54 & 17.35 & 14.88 & 13.57 & 14.84 & 14.62 & 15.81 & 16.58 & 12.79 & 15.71 & 10.87 \\
\hline $\mathrm{FeO}$ & 11.02 & $31.3 *$ & 8.32 & 11.69 & 15.74 & 12.58 & 12.92 & 12.86 & 7.9 & 13.20 & 12.40 & 13.05 \\
\hline $\mathrm{MnO}$ & 0.16 & 0.4 & 0.31 & & & & 0.2 & 0.17 & 0.37 & 0.33 & 0.16 & 0.66 \\
\hline $\mathrm{NiO}$ & 0.05 & 0.18 & 0.05 & & & 0.1 & 0.16 & 0.17 & 0.06 & 0.13 & 0.22 & 0.13 \\
\hline $\mathrm{Total}$ & 99.99 & 99.75 & 99.51 & 100.1 & 99.75 & 99.8 & 99.95 & 99.54 & 100.1 & 99.81 & 99.57 & 99.35 \\
\hline $\mathrm{Al}$ & 3.083 & 2.887 & 6.113 & 3.037 & 4.2 & 3.151 & 3.066 & 6.595 & 3.095 & 3.033 & 6.769 & 2.968 \\
\hline $\mathrm{Cr}$ & 12.07 & 11.05 & 8.908 & 12.135 & 10.928 & 12.451 & 12.363 & 8.261 & 11.78 & 12.42 & 8.630 & 12.043 \\
\hline $\mathrm{Fe}{ }^{3+}$ & 0.77 & 2.018 & 0.949 & 0.838 & 0.828 & 0.398 & 0.36 & 0.766 & 1.068 & 0.501 & 0.531 & 0.920 \\
\hline $\mathrm{Ti}$ & 0.039 & 0.028 & & & & & 0.039 & 0.048 & 0.011 & 0.03 & 0.070 & 0.069 \\
\hline $\mathrm{Mg}$ & 5.59 & 3.114 & 6.213 & 5.459 & 4.799 & 5.432 & 5.406 & 5.675 & 6.228 & 4.957 & 5.452 & 4.667 \\
\hline $\mathrm{Fe}+$ & 2.358 & 4.815 & 1.674 & 2.466 & 3.201 & 2.536 & 2.698 & 2.6 & 1.667 & 2.941 & 2.474 & 3.142 \\
\hline $\mathrm{Mn}$ & 0.011 & 0.097 & 0.064 & & & & 0.044 & 0.035 & 0.08 & 0.074 & 0.032 & 0.161 \\
\hline $\mathrm{Ni}$ & 0.020 & 0.035 & 0.01 & & & 0.032 & 0.033 & 0.034 & 0.012 & 0.028 & 0.042 & 0.030 \\
\hline $\mathrm{Cr \#}$ & 0.8 & 0.8 & 0.6 & 0.8 & 0.72 & 0.8 & 0.8 & 0.53 & 0.79 & 0.8 & 0.55 & 0.80 \\
\hline $\mathrm{Mg \#}$ & 0.7 & 0.39 & 0.78 & 0.67 & 0.60 & 0.68 & 0.66 & 0.68 & 0.78 & 0.63 & 0.56 & 0.60 \\
\hline
\end{tabular}


The PGE amount is about $2000 \mathrm{ppb}$ up to over $10.000 \mathrm{ppb}$ (Ohnenstetter et al., 1991; Neziraj, 1992). PGM are dominated by $\mathrm{Pt}+\mathrm{Fe}$ alloys, commonly isoferroplatinum and tetraferroplatinum, while other minerals as alloys of PGE $+\mathrm{BME}$ are less contained. The other characteristic of this mineralization is elevated content of $\mathrm{Rh}(4-5 \%)$. The composition of olivine: from mantle hartzburgites $\mathrm{Fo}=91.53-91.83$; from mantle dunites $\mathrm{Fo}=91.32-92.93$; Opx of mantle hartzburgites $\mathrm{En}=89.33-90.77$; Cpx Wo=47.2-49.6, En=49.65-49.96.

Some quartz-sulfide veined mineralizations of $\mathrm{Cu}$ and several lens-like ore bodies of $\mathrm{Cu}$ - Ni sulfidetype are related with gabbro - norite massifs.

\subsection{Kukesi massif}

The following ultramafc massif, Kukesi massif further south, is smaller, about $80 \mathrm{~km}^{2}$. In northern and western side it contacts with gabbro rocks, while to the east occur Triassic and Cretaceous limestones.

The distinguishing feature of this eastern ophiolitic massif is specific formational composition. It is composed partly by mantle harzburgites, but is dominated by dunite of transition zone, up to $800 \mathrm{~m}$ thick. Between dunite and gabbro massifs is observed a thin belt of $100 \mathrm{~m}$ thickness, composed mostly of wehrlites.

Kukesi ultramafic massif is also chromite-bearing. Several occurrences and any small chromatic deposit are situated within mantle hartzburgites. On the contrary, higher chromite-bearing potential belongs to thick dunitic sequence. There are also evidenced some horizons of layered bodies, composed of disseminated, schlieren and banded ores, with micro to fine-grained texture. Chromite belongs to Cr-rich metallurgic type, while its ore is low grade, containing $15-25 \% \mathrm{Cr}_{2} \mathrm{O}_{3}$. Disseminated and banded chromitic ores of like-layered shape ore bodies are observed also in thick dunite lenses, situated in upper parts of hartzburgite - dunite sequence. The size of some chromitite ore bodies reach to $1000 \mathrm{~m}$ in strike, and perform a gentle dip. In dunite, close to the contact with gabbro massifs is observed $\mathrm{Ni}$ - As maucherite mineralization.

\subsection{Lura massif}

Lura massif, situated in the south, is also small. It covers an area less than $100 \mathrm{~km}^{2}$. It is bounded to the east by Triassic limestone, whereas to the west is covered by Cretaceous limestones. This massif, consist mainly of mantle hartzburgites while dunites of the transition zone are very limited. Its chromite-bearing potential is limited, since there are only some occurrences and any small chromite deposit. The chromite belongs to Cr-rich metallurgic type (Table 1).

\subsection{Bulqiza massif}

Bulqiza ultramafic massif is situated at the west of Korabi microplate. The contact zone is usually marked by narrow belt of ultrametamorphic rocks of amphibolites and green-schist facies. The western flank is covered by molasse sediments of Burreli depression, whereas in southwestern flank, are located Triassic limestones. Further south, the Labinot - Diber transverse zone divides the Mirdita ophiolite belt in two sectors.

This massif covers a large territory, about $350 \mathrm{~km}^{2}$ while the ultramafic section is very thick about 3-5 km. This massif is dominated by mantle hartzburgites with any dunitic lens. The upper part of hartzburgite sequence switches to a hartzburgite - dunite composition, and above continue dunites of transition zone, situated on southern and western part of the massif. This sequence has a considerable thickness, about $300-500 \mathrm{~m}$. Further on are observed cumulate ultramafics, plagioclas dunites, pyroxenites and wehrlites, not very thick $(50-150 \mathrm{~m})$. Some small massifs of gabbro rocks occur in the western edge of the massif. In addition to these, for Bulqiza massif is characteristics presence of intrusive ultramafic wehrlitic bodies (Bebien et al., 1995). 
There is a high level of magnesium in Bulqiza massif composition since rock-forming minerals are orthopyroxene and olivine. In addition, they are enstatite $\mathrm{En}_{90-92}$ and forsterite $\mathrm{Fo}_{90-93}$ mineral-types respectively, whereas olivine of chromitite is extremely forsteritic $\mathrm{Fo}_{93-96}$.

The grade of partial melting of mantle, results to be very high about 25\% (Beqiraj et al., 2001). Another distinguishing feature of Bulqiza ultramafc massif is its metallogeny, which can be proved by presence of highly intensive chromite mineralization, as well as some other mineralizations, such as PGE and Ni-S (Karaj, 1992; Çina, 2010). Chromite mineralization is related with some sequences of ultramafic section, concretely in mantle hartzburgite, hartzburgite - dunite/or mantle dunite hartzburgite, dunite of transisition zone and in ultramafic cumulate sequence. Thin Cr-picotite bands are observed also in troctolites.

In Bulqiza massif occur many occurrences and some middle sized, large and very large chromite deposits. Among them can be mentioned Bulqiza deposit, which in resources and extraction reaches about 25 milion ton. The highest chromite mineralization is related mainly to mantle hartzburgites and partly with dunites of transition zone. Ore bodies are lens-like - platy shaped, whereas some other ore bodies are platy folded (Bulqiza deposit) and pencil-like (Shkalla deposit). They are very large: ore bodies of Bulqiza - Batra deposit are $5 \mathrm{~km}$ in strike and $500-1200 \mathrm{~m}$ dip. Ore bodies are exploited from an altitude of $1570 \mathrm{~m}$, down to $200 \mathrm{~m}$, though resources are located down to $300 \mathrm{~m}$ below sea level. The principal ore body of Shkalla deposit is oval - shaped of horizontal section, about $25 \mathrm{~m}$, whereas in dip $1500 \mathrm{~m}$. In dunite sequence of transition zone are observed some horizons of layered bodies, composed by low grade, disseminated, schlieren and banded ores (Krasta deposit). According to structural classification are evidenced concordant, subconcordant and discordant chromite ore bodies (Meshi et al., 2005; Çina and Meshi, 2013) (Figure 3).

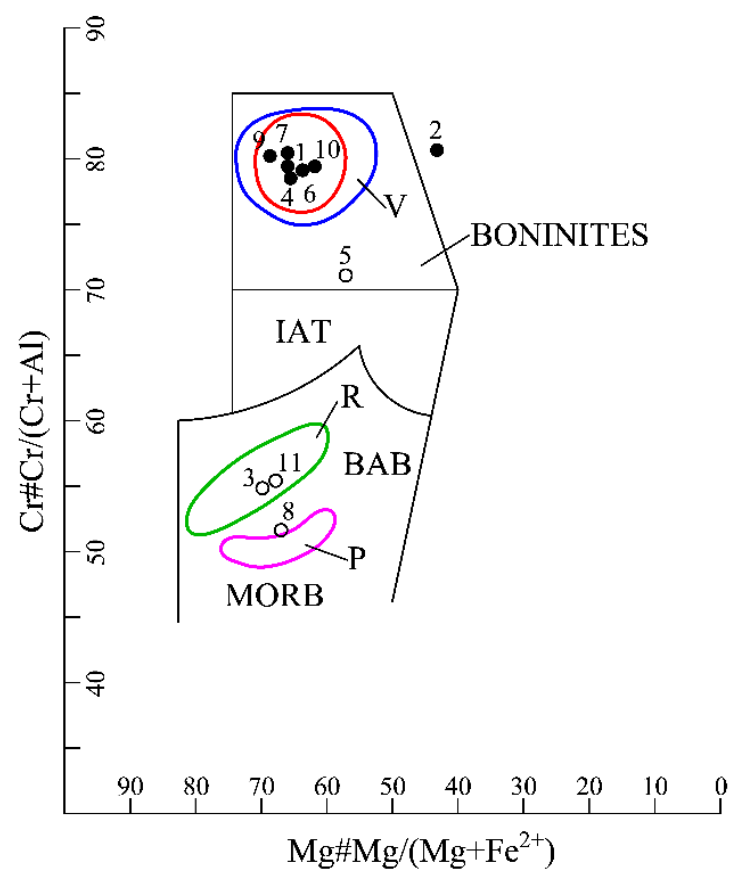

Figure 4 - Cr\# versus Mg\# of chromite from Albanian chromitite, eastern ophiolitic belt (1- 11) and average composition of Vourinos massif (V), Rodiani (R) area and

Pindos massif (P) (Economou et al., 1986) with reference to boninitic lavas from western Pacific, IAT, BAB and MORB environments (after Dick and Bullen, 1984).

Almost on the whole chromite of this massif belongs to Cr-rich metallurgic type, with $\mathrm{Cr} /(\mathrm{Cr}+\mathrm{Al})$ averagely $0.78-0.82$ and $\mathrm{Mg} /\left(\mathrm{Mg}+\mathrm{Fe}^{2+}\right)$ averagely $0.61-0.68$ (Figure 4). Difference is at The 
chromite of deposits occur in cumulate ultramafics is composed by A-rich type, $\mathrm{Cr} /(\mathrm{Cr}+\mathrm{Al})$, about 0.52 (Çina et al., 1986; Çina 2010). Olivine of mantle hartzurgites Fo=90.80-91.60 and from mantle dunites $\mathrm{Fo}=91.73-92.74$; Opx of mantle hartzburgites $\mathrm{En}=89.5-91.0$ and $\mathrm{Cpx}$ Wo=47.08-47.75 $\mathrm{En}=49.09-49.7$; olivine of chromitites Fo=93.98-96.59.

Another characteristics of Bulqiza massif, is presence of Ni-S, pentlandite mineralization, occurs as disseminations in dunite + chromite sequence of transition zone. With this mineralization are associated PGE in high quantity, reaching to $2200 \mathrm{ppb}$ (Krasta deposit). Similarly another mineralization is that of chromite, associated with $\mathrm{Ni}$ - sulfide and PGE, reaching to $9000 \mathrm{ppb}$. This mineralization is related with cumulate ultramafites of western side of the massif were occur Cerruja, Rrasa Martin, Kunji i Gjate deposits (Ohnenstetter et al., 1991; Karaj, 1992).

\subsection{Shebenik-Pogradeci massif}

At southeastern end of ophiolitic belt, is situated Shebenik - Pogradec ultramafic massif, dominated by mantle hartzburgites. Other rock components, dunite of transition zone, are limited. This massif contains some chromite occurrences and deposits with reserves vary from 0.5 to $1 \mathrm{mln}$ ton, composed by average to high grade ores (Katjel and Pojska deposits). This mineralization is related with mantle hartzburgites and only some chromite occurrences occur in dunites of transition zone. Chromite, for both groups of mineralizations, belongs to Cr-rich type, $\mathrm{Cr} /(\mathrm{Cr}+\mathrm{Al})=0.80-0.81$, whereas $\mathrm{Mg} /\left(\mathrm{Mg}+\mathrm{Fe}^{2+}\right), 0.63-0.68$. This area of Librazhd-Pogradeci is distinguished also for presence of a large $\mathrm{Fe}-\mathrm{Ni}$ mineralization and particularly of $\mathrm{Ni}$-silicate lateritic type.

\subsection{Vourinos massif}

In Greek territory as the continuation of Albanian eastern ophiolitic belt is situated the largest Vourinos ultramafic massif covering an area of $450 \mathrm{~km}^{2}$.

Based chiefly on geochemical investigations (Beccaluva et al., 1984; Konstantopoullo and Economou-Eliopoulos, 1990), the Jurassic ophiolites have been proposed as supra-subduction and island arc composition.

The Vourinos ophiolite contains the largest producing chromite mines in Greece. Chromite ores are related with tectonite and cumulate parts of ophiolite section. Here ores occur as minor layers in dunite bases.The grade of $\mathrm{Cr}_{2} \mathrm{O}_{3}$ in chromitite ores vary from 12-18-25\%. As for disseminated and schlieren ores, is $35-50 \%$. All economic concentrations are found in $2-3 \mathrm{~km}$ thick stratigraphic zones at the below the cumulate-tectonite contact. Chromite deposits are related with dunite host rocks of two types, as following: cumulate rocks, associated with ophiolitic magmatic suite and deformed bodies within mantle level sequence of ultramafic tectonites (Economou et al., 1986; Rassios et al., 1990).

In Vourinos massif, most of chromite mineralization belongs to C-rich type with $\mathrm{Cr} / \mathrm{Cr}+\mathrm{Al}) 0.79$ - 0.82 , whereas $\mathrm{Mg} /\left(\mathrm{Mg}+\mathrm{Fe}^{2+}\right)$, averagely $0.62-0.68$ whereas some other types related with cumulates, are composed of chromite of Al-rich type with ratio $\mathrm{Cr} /(\mathrm{Cr}+\mathrm{Al}) 0.58, \mathrm{Mg} /\left(\mathrm{Mg}+\mathrm{Fe}^{2+}\right)$ 0.63. Chemical composition of chromite ores leads to the idea, that Vourinos is formed from an environment, characterized by a higher grade of partial melting, that's why this eastern ophiolite zone contains Cr-rich type chromite ore (Economou et al., 1986). The PGE content, related to chromitite, is very low, about $100-200 \mathrm{ppb}$, whereas the Chondrite normalized patterns show similarity for chromitite of Bulqiza, Vourinos, Turkey and Oman (Economou, 1983, 1986; Ohnenstetter et al., 1991; Alliu et al., 1994).

The Pindios massif as southern continuation of Albanian western ophiolitic belt contains a few of Al-rich chromite occurrances (Economou-Eliopolis and Vacandios, 1995) any of them are metamorphoused (Kapsiotis et al., 2007). 


\section{Conclusions}

The Albanian eastern ophiolitic belt is formed by relatively homogenous hartzburgite mantle, nevertheless its evident the lithofacial and metallogenic variation along north-south direction.

This relatively variation of Albanian eastern ophiolitic belt was conditioned to a certain grade of different degree of partial melting of upper mantle, from the various intensity of mantle-peridotite residue action, by degree of development of magmatic cameras and from diverse activity of magmatic and post magmatic mineralizing processes.

The high chromite-bearing potential and the Cr-rich-type is conditioned by chiefly high magnesium and hartzburgitic composition of upper mantle as well as by high grade of its melting. The slow spreading, oxygen fugasity and the cool action of over layered crust have played also their role for this high chromite concentration.

\section{References}

Alliu, I., Beccaluva, L., Çina, A., Coltorti, M., Dobi, A., Gjata, K., Gjoni, V., Halku, A., Kodra, A., Premti, I., Saccani, E., Shallo, M., Siena, F., Stermasi, Sh. and Tashko, A., 1994. The Skanderbeg and Bulqiza mafic-ultramafic ophiolitic complexes and their relationship with chromititic ore deposits, Ofioliti, 19(1), 27-55.

Bebien, I. and Shallo, M., 1995. Intrusive ultramafic rocks in Albania ophiolites, EUG. 8, Strasbourg (abstract volume).

Beccaluva, L., Ohnenstetter, D., Ohnenstetter, M. and Paupy, A., 1984.Two magmatic series with island-arc affinity within the Vourinos ophiolite, Contribution to Mineralogy and Petrology, $85,253-271$.

Beccaluva, L., Coltorti, M., Saccani, E., Siena, F. and Zeda, O., 1994. Midocean ridge and suprasubduction affinities in the ophiolite belts of Albania, Ofioliti, 19(1), 77-97.

Beqiraj, A., Masi, U. and Violo, M., 2001. Geochemical characterization of podiformchromite ores from the Bulqiza ultramafic massif and hits for prospection, Journal of Exploration and Maining Geology, 9(2), 268-276.

Chiari, A., Marcucci, M. and Prela, M., 2004. Radiolarian assemblages from the Jurassic charts of Albania: new data, Ofioliti, 29(2), 95-105.

Çina, A., Casli, H. and Goci, L., 1986. Chromites in the ophiolites ofAlbanides. In: "Chromites", UNESCO)'s IGCP 197 project, Metallogeny of Ophiolites, Theophrastus Publ., Athens, 107126.

Çina, A., 2010. Mineralogy of chromitite, Bulqiza ultramafic massif, Albanian ophiolitic complex, 12th International Congress of the Geological Society of Greece, Patras, XLIII/5, 2577-2587.

Çina, A., 2010. Pentlandite mineralization related to Albanian ophiolites, XIX Congress of the Carpathian-Balkan Geological Association, Greece, 110, 317-323.

Çina, A. and Meshi, A., 2013. Later chromitites from ophiolites of Albania. In: Basalt 2013, Cenozoic Magmatism in Central Europe, 43-44.

Dick, H.J. and Bullen, T., 1984. Chromian spinel as a petrogenetic indicator in abyssal and Alpinetype peridotite and specially associated lavas, Contribution to Mineralogy and Petrography, 86, 54-76.

Economou, M., 1983. Platinum group metals in chromite ores from the Vourinos ophiolite complex, Greece, Ofioliti, 8(3), 339-356.

Economou, M., Dimou, E., Economou, G., Migiros, G., Vacondios, I., Grivas, E., Rassios, A. and Dabitzias, S., 1986. Chromite deposits of Greece. In: “Chromites”, UNESCO's IGCP 197 project, Metallogeny of ophiolites, Theofrastus publication, Athens, 129-159.

Economou-Eliopoulos, M. and Vacandios, I., 1995. Geochemistry of chromitites and host rocks from the Pindos ophiolite complex, northwestern Greece, Chemical Geology, 122, 99-108.

Hoeck, V., Koller, F., Meisel, T., Onuzi, K. and Kneringer, E., 2002. The Jurassic South Albanian Ophiolites: MOR-vs SSZ-type ophiolites, Lithos, 65, 143-164. 
Kapsiotis, A., Tsikouras, B., Grammatikopoulos, T., Karipi, S. and Hatzipanagiotou, K., 2007. On the metamorphic modification of Cr-spinel compositions from the ultrabasic rocks of the Pindos ophiolite complex (NW Greece), Bulletin of the Geological Society of Greece, Procedings of the 11th International Congress, XXXX, 781-793.

Karaj, N., 1992. Repartition des platinoides des chromites et sulfures dans le massif de Bulqiza, Albanie. Incidence sur les proccesus métallogeniques dans les ophiolites, Thèse, Univ. d'Orléèans, $400 \mathrm{pp}$.

Kodra, A., Gjata, K. and Bakalli, F., 1995. The Mirdita oceanic basin from rifting to the closure. In: Workshop on Albanian ophiolites and related mineralizations, Documents du BRGM 244, Edition BRGM, France, 9-26.

Koller, F., Hoeck, V., Ionescu, C. and Onuzi, K., 2009. Contrasting mantle section in Albanian ophiolites: evidences from mineral and bulk rock composition. In; MinPet 2009 and 4th Mineral sciences in the Carpathians Conference, Budapest, Band, 155, 84.

Konstantopoulou, G. and Economou-Eliopoulos, M., 1990. Geochemistry of the Vourinos chromite ores, Greece. In: Ophiolites, Oceanic crustal Analogues, Symposium “Trodoos 1987”, Nicosia, Cyprus, 605-613.

Manika, K., 1994. Pétrologie du massif ophiolitique de Shebenik, Albanie, Thèse, Univ. de ParisSud, 297 pp.

Meshi, A., Hoxha, I. and Milushi, I., 2005. Chromitites in Mirdita ophiolite (Albania); Structure and genetic implications, Journal of Alpine geology, 49, 1-29.

Neziraj, A., 1992. Etude pétrologique et métallogenique du massif ophiolitique de Tropoja, Albanie. Reference particuliere aux gisements de chromite et éléments du group du platine, Thèse, Univ. d'Orléans, France, 544 pp.

Nicolas, A., Boudier, F. and Meshi, A., 1999. A slow spreading accretionin the ophiolite of Mirdita (Albania), Journal of Geophysical Researcher, 104(87), 15155-15167.

Ohnenstetter, M., Karaj, N., Neziraj, A., Johan, Z. and Çina, A., 1991. Le potential platinifere des ophiolites: minéralisations en éléments du group du platine (PGE) dans les massifs de Tropoja et Bulqiza, Albanie, C.R. Acad. Sci. Fr., 313(II), 201-208.

Rassios, A. and Kostopoulos, D., 1990.The geochemistry of dunite and its relation to the position of chromitites in the Vourinos, Ophiolite complex, Greece, In: Ophiolites, Oceanic Crustal Analogues, Symp. "Trodoos 1987”, Nicosia, Cyprus, 593-603.

Shallo,M., Çina, A. and Turku, I., 1995.Outline of the metallogeny of the Albanian MOR and SSZtype ophiolites. In: Workshop on Albanian ophiolites and related mineralizations, Documents du BRGM244, editions of BRGM, France, 27-46.

Tashko, A. and Gjata, K., 1990. Rreth gjeokronologjise absolute te masiveve ultrabasike te Albanideve, Bul. Shkenc. Gjeol., 1, 39-50. 